\title{
Moroccan oil slick disperses
}

Parls

MAN and nature have finally almost dispersed a huge oil slick from the damaged Iranian tanker, Kharg-5, which has threatened the Atlantic coast of Morocco for the past three weeks. The 70,000 tons of light oil which spilled into
Smit Tak was refused permission to tow the tanker to shelter nearer the shore by both the Spanish and the Moroccan governments, which feared the pollution risk was too great. This, say Smit Tak and some ecology groups, such as Greenpeace, may have made matters worse,

\section{IMAGE UNAVAILABLE FOR COPYRIGHT REASONS}

The Iranian supertanker Kharg-5 - it could all happen again.

the sea after explosions on board the tanker have now either evaporated or been dispersed with chemicals, leaving some 500 tons slowly being blown out to sea, according to the latest reports. Meanwhile the Kharg-5 is being towed off the Canary Islands in search of shelter, with a 200 -square-metre hole in her hull and 200,000 tons of oil still in her tanks.

At the end of last week, some reports from Morocco estimated the oil slick to be 175 miles long and, at 35 miles offshore, still a major threat to Moroccan beaches, sardine fisheries and oyster beds between Casablanca and Safi. But, although the Moroccan authorities now insist that there is no longer any real danger of major pollution, the coast is still under close surveillance from ocean-going tugs and light aircraft.

Morocco seems to have escaped lightly. The authorities were almost totally unprepared for an accident of this kind and the expertise and equipment needed to disperse the slick and to prevent it fouling the beaches came mostly from France and Britain. Kharg-5 drifted for two days in heavy seas after its 32-man crew abandoned ship following explosions in one of its tanks on 19 December. During this time, an estimated 70,000 tons of light oil spilled into the sea, while the damaged tanker drifted from the site of the explosion, off the Canary Islands, towards Rabat on the Moroccan coast near the Straits of Gibraltar

When the Moroccan authorities learned of the accident in their territorial waters, they demanded that the ship's owners, the Iranian Tanker Company, take responsibility for salvage operations. The company contracted a Dutch salvage firm, Smit Tak, which flew experts out to the Kharg-5 on 22 December. The fire was brought under control, but heavy seas prevented either repairs to the hull or transfer of the 200,000 tons of oil to a sister ship sent by Kharg-5's owners. since the only remaining solution was to tow the Kharg-5 further out to sea, in a storm, towards the Canary Islands some 300 miles away. The decision of the Moroccan and Spanish governments, complain Smit Tak, caused delays which allowed more oil to spill into the sea than if a speedy repair had been carried out, while leaving the threat of further pollution by Kharg- 5 still untackled.
According to French environment minister Brice Lalonde, who flew to Rabat on 2 January, oceanographer Jacques-Yves Cousteau first told him of the accident. The French quickly supplied chemical dispersants and a team of experts from Brest, set up after the Amoco Cadiz spill polluted Britanny beaches in 1978 . The British sent out inflatable barrages to protect the shore - in particular the valuable oyster beds at Oualidia.

While the immediate danger to Morocco's shores has been averted, the possibility of an even greater accident, should Kharg-5 break up, has still not been dealt with. If the Spanish and Moroccan governments do not change their minds and let the tanker enter sheltered coastal waters, it may be impossible either to repair the hole in the ship's hull or to transfer the oil to another tanker. The solution of destroying the tanker and its cargo with explosives is not winning support - both because it may fail, and because it would deprive Smit Tak of valuable salvage. The wandering tanker has also highlighted a weakness in international maritime law. No authority apparently exists to oblige Kharg-5's owners to prevent a further accident while the ship is in international waters.

Peter Coles

\section{Juno programme outlined}

\section{London}

Although the joint Anglo-Soviet manned space mission Juno was given the official go-ahead only in June last year, a roster of scientific experiments for the sixday mission has already been assembled. Details of the science programme were announced last week in London. Despite the compressed timescale - Juno is set for launch in April 1991 - Heinz Wolff, science director for the mission, has "no reservations whatsoever" about the standard of the 26 shortlisted microgravity experiments. A single British astronaut (Tim Mace or Helen Sharman) will spend six days aboard the Mir space station, but it is not yet clear what proportion of the planned 40 working hours will be devoted to science.

Experiments ranging from materials science to psychology are planned. In one of the largest experiments, the crystallization of up to 1,000 protein samples will be studied, following indications from experiments aboard the US space shuttle that larger and more ordered crystals may grow in low gravity. If this is the case, then a better knowledge of the structures of proteins can be obtained in a microgravity environment, but more than six days may be needed for a useful experiment to be done. Wolff is now in Moscow for several days hoping to persuade the Soviets to continue with the experiment after the departure of the British astronaut.

Other experiments, involving cell culture and fungus growth, may benefit from a shorter flight time because of the difficulties of storing delicate biological material for long periods. A final list of the experiments, probably 18 in number, that will be flown on Juno will be announced later this month after Wolff's negotiations in Moscow are concluded.

The whole budget for the British side of the mission will come from commercial sponsorship. Out of a total of $£ 16$ million, only $£ 2.3$ million has been allocated to the science programme, a fraction of what is typically spent on microgravity experiments on similar flights.

Peter Graham, mission director, believes that the progress of Juno's experiments will be watched closely by the European Space Agency (ESA) and the US National Aeronautics and Space Administration (NASA) to see if this low-budget approach yields useful science.

The British National Space Centre and the Science and Engineering Research Council (SERC) will also be observing Juno with interest, following the decision by SERC in August 1989 to pull out of ESA's microgravity research programme (see Nature 340, 493; 1989).

Peter Aldhous 